\title{
The Effect of Free Trade and The Economic Globalization toward Rupiah's Stabilization
}

\author{
Andi Triyawan ${ }^{1}$, Hamidah Tussifah ${ }^{2}$, Syahruddin ${ }^{3}$, Rif'at Husnul Ma'afi ${ }^{4}$, Harda \\ Armayanto ${ }^{5}$ \\ \{ andritriyawan@unida.gontor.ac.id ${ }^{1}$, hamidahtussyifa@unida.gontor.ac.id $^{2}$, \\ syahruddin@unida.gontor.ac.id ${ }^{3}, \underline{\text { rifathaem@ gmail.com }}{ }^{4}$, harda@ unida.gontor.ac.id $^{5}$ \}
}

Universitas Darussalam Gontor, Siman KM 62 Demangan, Ponorogo, Indfonesia ${ }^{1,2,3,4,5}$

\begin{abstract}
Economic globalization is one of the international agendas that almost all countries cannot avoid. The movement of economic globalization creates a free trade between countries so that the free trade system is in high demand by several countries in the world. The purpose of this study was to find out how the influence of the movement of economic globalization and growing free trade on the stability of the rupiah exchange rate in Indonesia in 2017. The data used was obtained from secondary data taken from the Indonesian Economic Report, Central Statistics Agency, and Quarterly reports OJK IV2017. Meanwhile, the data collected is obtained through some documentation. According to the results of research and economic reports by Bank Indonesia, the rupiah exchange rate has stabilized throughout 2017, and this is indicated by the Indonesian payments that recorded a surplus.
\end{abstract}

Keywords: Economic Globalization, Free Trade, Rupiah.

\section{Introduction}

Economic development in several countries has now increased with the existence of economic globalization. Economic globalization can influence relations between countries in all types of state needs, as well as in international trade. In this case, the positive side of the globalization movement has an impact on increasing state revenues, because of the ease in the dissemination of technology that can facilitate production, provide access to global capital, have comparative advantages, spread human rights and increase employment opportunities.

This effort can improve people's welfare. By looking at this positive side, some economists argue that globalization can encourage a country to improve people's welfare. Conversely, It is a country with low potential such as in terms of skills and capital, management, exploitation of workers, unstable global capital markets, national culture, the autonomy of the national economy. In this case, the poorer countries will weaken with the movement of globalization and inevitably have to accept policies made by more prosperous countries.

Also, the issue of the development of globalization and free trade was agreed upon by several countries at one of the ASEAN ministerial meetings. With a free trade agreement between ASEAN countries, Indonesia as an ASEAN member in facing the program certainly cannot refuse or say it is not ready. This freedom will lead to competition in producing goods. And what is now the record is that materialism cannot be criticized with materialism. In other 
terms, conflict cannot be overcome by conflict. According to Ichsanuddin Noorsy in this free market problem he revealed:

"They have for centuries applied conflicts with physical violence. When converted to a model of thinking, the form is by disseminating the free market, that's how they live".

In the open economy or the economy of the four sectors, as is the case for Indonesia, the economic condition of a country will significantly influence the main variables in other countries' macroeconomics both in the monetary, fiscal and real sectors. Whereas in Law Number 3 the Year 2004 No. Article 7 of Law Number 6 the Year 2009 stipulates that Bank Indonesia is the institution that has the right and duty to achieve and maintain the stability of the rupiah value. Thus, the agreement between countries on the policies of economic globalization and free trade has now become a fiscal authority.

Since 1993, Indonesia began to compete in the ASEAN free trade union. In the free trade movement, the community seeks to improve the competitiveness of the export product industry. In terms of empowering the industry sector, Gati Wibawaningsih considers that the implementation of the ASEAN Economic Community is one of the opportunities and challenges for the domestic creative industry [1].

When this creative industry dares to compete in the era of economic globalization, they can compete. In 2015, as recorded in Indonesia's total GDP, around Rp. 642 trillion or 7.05 percent up from the previous year. It is a form of product competitiveness in the free market. Tighter competitiveness has implications for the rupiah exchange rate from year to year, especially at the end of 2017 closed at the level of Rp13,568 per US dollar. It is not much different compared to the position at the end of 2016 which reached IDR 13,473 per US dollar."

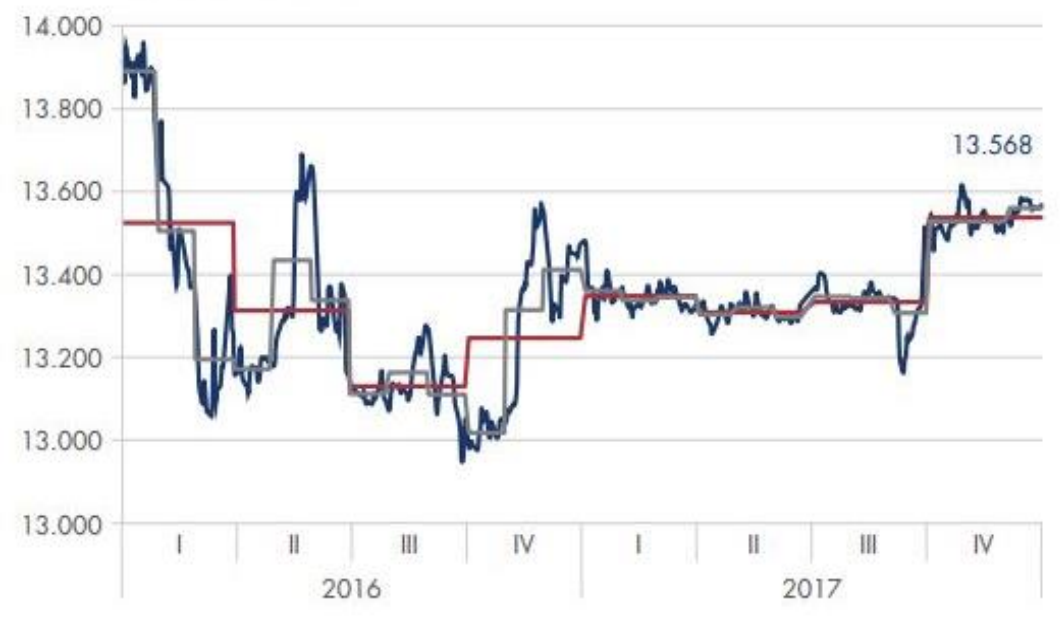

Fig. 1. Fluctuation of rupiah's currency 2017

The occurrence of the depreciation of the rupiah against the dollar is not a foreign matter, but a global phenomenon. That is, the USD can weaken almost all world currencies. 


\section{Discussion}

\subsection{Economic Globalization}

Globalization is the term human relations in the whole world. This relationship can be through trade, travel, investment, popular culture, and other forms of interaction to remove a limit on the country. Globalization is also a consequence of the ease in information, technology, and communication that has a broad impact on the political, cultural, social and economic fields [2].

Globalization according to scholars is divided into several groups, namely:

The hyperglobalist group assumes that globalization is a history of human life where a traditional country is no longer relevant. This group saw that the movement of economic globalization would bring the phenomenon of "denationalization" of the economy through transnational, trade and financial production networks. This group considers that economic globalization processes the development of new social organizations that will replace the nationstate as the primary economic institution and political unit of the world community. The hyperglobalist group also states that the emergence of the global economy, global governance institutions, and the spread and cultural hybridization are regarded as facts of the new world order.

Transformationalist groups assume that globalization plays a role as the main force behind social, economic, political changes that are redefining modern society and the world order. Whereas the skeptics argue that globalization is not a new phenomenon but has a long history, and of course global power now depends on the power to regulate from the national government to guarantee continuous economic liberalization because theoretically trade liberalization affects the level of welfare. The symptoms of this globalization have an impact on financial activities, production, and trade which will affect the economic relations between nations. From some of the opinions of the scholars, it can be concluded that economic globalization is a movement that will gradually form a new authority in mastering the economic activities of the entire country.

\subsection{Free trade}

Market or trade activities at the end of this decade are focused on the issue of free trade or international business. Free trade is one of the influences of economic globalization that has developed and enforced forcefully as a new law that can regulate the economic system. International trade can be interpreted as an activity of transactions in goods and services that are agreed among countries. In the free trade, there is a reduction or elimination of trade barriers between countries, both tariff (export and import) and non-tariffs, quotas, dumping and so on [3].

Import tariffs imposed on imported goods will increase prices in the domestic market so that domestic producers can enjoy a more massive surplus and consumers face a high price of these goods. Besides that, trade liberalization provides an opportunity for countries to carry out a division of labor and specialization in the production of goods and services, where they can produce these goods relatively cheaply. However, the formation of this free trade made nonmember countries less willing to cooperate with multilateral free trade. 


\subsection{Exchange Rates}

Exchange rates are also referred to as the price of foreign currency in domestic currency, so that when a country's exchange rate increases, the increase can affect the price of foreign exchange and vice versa. In a floating exchange rate, the foreign exchange rate is determined by the strength of demand and supply on the foreign exchange market.[4] Two main factors that can influence fluctuations in foreign exchange rates are the demand for foreign exchange and foreign exchange money offers.

The demand for the foreign exchange itself is influenced by four factors, namely the payment of imports of goods and services, capital outflows, speculation activities, and Central Bank foreign exchange intervention. (Bao and Wang 2019) The foreign exchange offers are influenced by the receipt of exports of goods and services, capital inflows, and Central Bank foreign exchange interventions.

\subsection{The Role of Bank Indonesia as the Authority to Control the Stability of the Rupiah}

One of the roles of Bank of Indonesia in the economy is as the controlling authority and maintaining the stability of the rupiah value, as stated in Law Number 23 the Year 1999 and has been perfected by Law Number 3 the Year 2004 and Law Number 6 the Year 2009 article 7 . The stability of the rupiah value consists on two aspects, namely the stability of goods and services and stability of the currencies of other countries (exchange rates), besides this stability also affects the inflation rate. (Meyer 2018)

However, now the task of regulating and supervising banks is held by the OJK, under the Republic of Indonesia Law Number 21 of 2011 concerning the Financial Services Authority (OJK) on December 31, 2013, or effective January 1, 2014. Activities in the financial services sector can regularly organize, equitably, transparently and accountably realizing a financial system that grows sustainably and stable. Become a protector of the interests of consumers and society.

\subsection{Research Results}

The existence of inter-country trade strengthens free trade without obstacles, or there is a decrease in customs tariffs by $0-5 \%$ to increase economic competitiveness between the countries whereas globalization is a consequence of ease in information, technology, and communication that has a broad impact on the political, cultural, social and economic fields. The free trade is assumed by allowing the market mechanism to run freely in the absence of government or state interference. Thus the economy will move based on market mechanisms.

Also, deregulation of capital, labor and commodity markets is assumed to accelerate economic growth. The dependence of economic conditions between countries is a consequence of the impact of economic globalization and free trade which will affect the dependence of factors that affect the stability of currency exchange rates. In the Indonesian context, as mandated in Law Number 23 the Year 1999, Law Number 3 the Year 2004 and Law Number 6 the Year 2009 explain that state institutions specifically mandated to control the stability of the rupiah, including external stability reflected in the exchange rate are Bank Indonesia. (Scott, Yoto, and Yotov 2016) 
The value of money that can be directly affected by the globalization of the economy and this free market is obvious value. The dynamics of the rupiah exchange rate throughout 2017 are divided into two main periods, namely the first quarter until the end of the third quarter of 2017 which moves relatively stable. While in the second period at the end of the 3rd semesters until the end of 2017, the rupiah exchange rate weakened.

On the other hand, an increase in global investors towards the national economy contributes to minimizing some of the global risks that can trigger pressure on the rupiah exchange rate. Also, some global risks that have an impact on the development of the rupiah are related to developments in the US, Europe, and China. This uncertainty in the implementation of US policy puts pressure on the weakening of the US dollar globally.

In the context of the implementation of free trade, Indonesia has been actively involved in various Free trade Area (FTA) trade agreements. The government as a fiscal authority, through its three fiscal policy instruments, namely in the form of taxes, transfer payments and expenditure that need to make strategic policies to support exchange rate strengthening. [8] Such as allocating investments through State-Owned Enterprises (BUMN) in the business sector that encourage increased exports and optimization of processing of production factors.

So, the high demand for foreign exchange can push up the value of foreign currencies and weaken the domestic currency and can be controlled. It is a market opportunity for potential export products of various regions in Indonesia. Usually, Indonesia is considered a major producer of fossil fuels, and one of the largest producers and exporters in the world of coal, especially thermal coal. In 2017, based on data from the Indonesian Ministry of Trade, Indonesia's trade recorded a surplus of USD 11.83 billion cumulatively.

In November 2017, it was noted that the value of Indonesian exports could reach the US \$ 15.28 billion, an increase of 0.26 percent compared to exports in October 2017. While in November 2017 it increased by 13.18 percent. Meanwhile, non-oil and gas exports in November could reach the US \$ 14.01 billion, up 1.82 percent compared to October 2017 whereas compared to non-oil and gas exports in November 2016 it rose 13.00 percent. Then cumulatively, the value of Indonesia's exports was able to reach the US \$ 153.90 billion, an increase of 17.16 percent compared to the 2016 period, while non-oil and gas exports reached the US \$ 139.68 billion and increased by 16.89 percent.

Changes that have taken place on the aggregate demand and supply side will certainly implicate directly on the price and simultaneous balance that occurs. From the increase in Indonesian exports, the rupiah exchange rate in 2017 then moved stably with low volatility. Fundamental factors also support this development. Indonesia's balance of payments recorded a surplus, improved foreign exchange market conditions, as well as Bank Indonesia's policies that led to exchange rates by its fundamental values, and external risks in 2017. Generally, the dynamics in 2017 led to a stronger and relative rupiah value stable until the end of the third quarter, although in the fourth quarter of 2017 the rupiah had weakened cause driven by external factors. This weakness is related to the direction of normalization of developed country monetary policy and uncertainty in the direction of US economic policy.

\section{Conclusion}

Globalization is the term human relations in the whole world. This relationship can be through trade, travel, investment, popular culture, and other forms of interaction to remove a 
limit on the country. Globalization is also a consequence of the ease in information, technology, and communication that has a broad impact on the political, cultural, social and economic fields.

The existence of inter-country trade strengthens free trade without obstacles, or there is a decrease in customs tariffs by $0-5 \%$ to increase economic competitiveness between the countries whereas globalization is a consequence of ease in information, technology, and communication that has a broad impact on the political, cultural, social and economic fields.

This free trade is assumed by allowing the market mechanism to run freely in the absence of government or state interference; thus the economy will move based on market mechanisms. Also, deregulation of capital, labor and commodity markets is assumed to accelerate economic growth. Economic globalization and free trade have implications for the stability of the rupiah value so that Bank Indonesia as the monetary authority is responsible for achieving and maintaining rupiah stability that has a big challenge.

Therefore, Bank Indonesia must be more stringent in maintaining the stability of the rupiah exchange rate. With various efforts, the dynamics of the rupiah exchange rate in 2017 were generally quite stable, supported by improving Indonesia's economic fundamentals, despite having experienced pressure in the last quarter due to external factors.

\section{References}

[1] A. Aritenang and J. W. Sonn, "The effect of decentralization and free trade agreements on regional disparity in a developing economy: the case of Indonesia, 1993-2005," Int. J. Urban Sci., vol. 22, no. 4, pp. 546-564, Oct. 2018.

[2] L. Linsi, D. Mügge, and L. Linsi, "Globalization and the Growing Defects of International Economic Statistics," 2, 2017.

[3] T. N. Doan and Y. Xing, "Trade Efficiency, Free Trade Agreements and Rules of Origin," J. Asian Econ., 2017.

[4] W. Paper, "Impact of Free Trade Agreement Use on Import Prices," no. April, 2018.

[5] X. Bao and X. Wang, "The Evolution and Reshaping of Globalization : A Perspective Based on the Development of Regional Trade Agreements," vol. 27, no. 1, pp. 51-71, 2019.

[6] T. Meyer, "Free Trade, Fair Trade, and Selective Enforcement FREE TRADE, FAIR TRADE , AND SELECTIVE," no. March, 2018.

[7] L. Scott, V. Yoto, and Y. V Yotov, "Twenty Years of Trade Integration," 2016.

[8] S. L. Baier and J. H. Bergstrand, "Do free trade agreements actually increase members ' international trade?," vol. 71, pp. 72-95, 2007. 